\title{
Use of ornamental lilac and honeysuckle phenophases as indicators of rangeland grasshopper development
}

\author{
WILLIAM P. KEMP, JAMES S. BERRY, AND JOSEPH M. CAPRIO
}

\begin{abstract}
Comparisons were made between phenological phase dates of 2 common ornamental shrubs, purple common lilac (Syringa vulgaris L.) and Zabeli honeysuckle (Lonicera krolkowii Stapf, var. Zabelii (Rehd. Rehder)), and rangeland grasshopper (composite of 6 common species) development for 3 years at 9 sites throughout Montana. Results indicated that spring hatch (75\% instar 1) occurred about 10 days after the begin bloom phase of purple common lilac. Peak occurrence of grasshoppers for instar 2 coincided, on average, with the end bloom phase of Zabeli honeysuckle, whereas peak instar 3 occurred about 10 days later. On average, peak instar 4 preceded the first red berry phase of Zabeli honeysuckle by about 8 days, and $75 \%$ adult stage occurred about 14 days after red berries first appeared. Our results provide rangeland managers and ranchers with a simple method for the improved timing of assessment and control of rangeland grasshoppers.
\end{abstract}

Key Words: IPM, phenology models, rangeland insects, Lonicera krolkowii, Syringa vulgaris, grasshoppers, Acrididae, geostatistics

The sequence of activities involved in rangeland grasshopper pest management are generally triggered by the presence of specific life stages in the field. Grasshoppers commonly have 5 nymphal stages (instars 1-5) followed by the adult stage. Onsager (1987a, 1987b) states that the best time to evaluate rangeland grasshopper densities is at "peak instar $3^{n}$. Peak instar 3 refers to the point in time when we expect to have the highest proportion of instar 3 individuals for a given site and year. By assessing densities of grasshopper communities at peak instar 3, resource managers still have time to prepare for and apply biological or chemical control agents at the appropriate times (for example, at peak instars 4 and 5 or $25 \%$ adult).

A statistical model has been developed that describes insect

Authors Kemp and Berry are with USDA/ARS, Rangeland Insect Laboratory, Bozeman, Montana 59717-0366; Caprio is with Department of Plant and Soil Science, Montana State University, Bozeman 59717.

The authors wish to thank J. Holmes, K. Curtiss, T. Engle, D. Gillis, and V. Hagestad for technical assistance. The reviews and comments of early drafts of this manuscript by Dr. Stephen A. Woods, Dr. Jeffrey A. Lockwood, and Dr. Jerome A. Onsager are sincerely appreciated. Thanks also go to $S$. Osborne and $P$. Rowsey for manuscript preparation.

This work was supported in part by a cooperative agreement with the Grasshopper IPM Demonstration Program USDA-APHIS-PPQ, Boise, Idaho.

Manuscript accepted 31 January 1991.

JOURNAL OF RANGE MANAGEMENT 44(6), November 1991 phenology as a function of accumulated heat or degree days (Dennis et al. 1986, Dennis and Kemp 1988). The model (Dennis et al. 1986) and related statistical inferences (Dennis and Kemp 1988) can be used to develop estimates of the average date of occurrence for the different developmental phases of rangeland grasshoppers. However, resource managers are frequently not able to obtain the data (daily maximum and minimum temperatures, and grasshopper development) required for computing parameter estimates for the model. Therefore, it is important to evaluate the relationships between rangeland grasshopper phenology (using methods of Dennis et al. 1986 and Dennis and Kemp 1988) and other indicator variables such as plant phenophases.

Recognition that the annual progression of plant development has important implications to rangeland management is not new. Plant phenophases have been used to determine range readiness, to select for the timing of brush control (Hyder and Sneva 1955), and to describe climatic patterns (Caprio 1966). Developmental stages of indicator plants have also been associated with insects. For example, Hewitt (1979) found a loose association between later instar rangeland grasshoppers and phenological stages of $\mathbf{3}$ grass species at Roundup, Mont., over a 3-year period. Other studies of rangeland grasshopper populations (Hewitt 1980) have suggested a possible link between 14 rangeland forb species and an unidentified complex of grasshopper species during a 2-year study at 2 sites in Montana. However, because of the variability found in plant phenology that resulted primarily from precipitation patterns, Hewitt $(1979,1980)$ suggested that a combination of plants would be necessary to estimate grasshopper phenology.

Kemp (1987) suggested a link between peak instar 3 of rangeland grasshoppers, the end bloom phase of Zabeli honeysuckle (Lonicera krolkowii Stapf, var. Zabelii (Rehd. Rehder)), and begin bloom phase of purple common lilac (Syringa vulgaris L.) based on data collected during 2 years at 1 site. Use of ornamentally grown Zabeli honeysuckle and purple common lilac as phenological indicators for grasshoppers has several advantages over native range plants (Hewitt 1979, 1980). In the western United States, for example, there exists a network of purple common lilac and Zabeli honeysuckle observers who utilize standard methods in recording plant phase observations each year (Caprio 1966, Caprio et al. 1970). These plants are also extensively grown in home gardens throughout Montana. Further, because observers monitor the 
same plants each year and provide standardized care (for example, planting, watering, pruning, etc. (Caprio et al. 1970)), the progression of phenological stages of purple common lilac and Zabeli honeysuckle is a good indicator of total heat input at a given site (Caprio 1967, 1974). Attempts to relate plant development to the seasonal development of ectotherms such as grasshoppers are likely to be most successful where plant phenology is driven primarily by heat and is not influenced by both heat and precipitation, as was the case for native plants used in previous studies (Hewitt 1979, 1980).

The objective of this study was to examine the relationships between seasonal phenology of purple common lilac, Zabeli honeysuckle, and rangeland grasshoppers in Montana in order to provide resource managers a simple method for determining when grasshopper pest management decisions should be made. At present, such decisions require on-site sampling by trained individuals because no predictive development models exist that can be used by land managers.

\section{Methods}

\section{Indicator Plant Phenology Data}

Phenological observations on both purple common lilac and Zabeli honeysuckle were made during 1986-1988 at about 40 locations throughout Montana, eastern Idaho, and northern Wyoming. These plant phenological observations are part of an ongoing study of large scale spatial patterns of plant phenology throughout the western United States (Hopp 1974). Within this network, observers follow standard procedures for planting, maintenance, and observation for both purple common lilac and Zabeli honeysuckle (Caprio et al. 1970). For each year, a relationship was developed between elevation (Table 1) and each of 3 selected plant

Table 1. Elevation correction coefficients (days/30.5m) used to adjust the phenology dates for the interpolation process.

\begin{tabular}{lccc}
\hline \hline & 1986 & 1987 & 1988 \\
\hline Begin bloom purple common lilac & 0.91 & 0.68 & 0.95 \\
End bloom Zabeli honeysuckle & -1 & -2 & 1.03 \\
First red berry & 1.04 & -3 & 1.18 \\
95\% red berry & 0.90 & 0.84 & -4 \\
\hline
\end{tabular}

I Kriging was not successful. Mean number of days from begin bloom to end bloom was calculated ( 23.7 days) and added to the interpolated begin bloom dates on a per grid location basis (cell).

2There was not a significant coefficient for elevation correction. However, a significant regression (Interval (days) $=-4965.0+212.78 *$ latitude $-2.2639 *$ latitude 2 ) was found to estimate the number of days from begin bloom to end bloom. This interval (days) was calculated on a per cell basis and added to the interpolated dates for begin bloom ${ }^{3}$ There was not a significant coefficient for elevation correction. However, a significan regression (Interval (days) $=55.43+-0.2693 *$ latitude) was found to estimate the number of days from first red berry to $95 \%$ red berry. This interval (days) was calculated on a per cell basis and substracted from the interpolated dates for $95 \%$ red berry.

There was not a significant coefficient for elevation correction. The interval from first red berry to $95 \%$ red berry was calculated for each observed data point. Kriging was used to interpolate these intervals. These interpolated intervals were added to the interpolated dates for first red berry.

development stages (begin bloom phase of purple common lilac', end bloom phase of Zabeli honeysuckle ${ }^{2}$, and first red berry phase of Zabeli honeysuckle ${ }^{3}$ ). These relationships were used with an interpolation method known as block kriging to produce a normalized map for each development phase at an elevation of $1,216 \mathrm{~m}$ (Englund and Sparks 1988, Robertson 1987) except where noted in Table 1. These maps were then used together with the derived relationship with elevation to estimate the Julian date (by year) for each plant phase within $12.87 \mathrm{~km}^{2}$ cells throughout Montana. If the elevation of a cell differed by more than $30.5 \mathrm{~m}$ from the actual elevation of a grasshopper monitoring site, an additional lapse rate adjustment was made on the estimated event date of a

1Begin bloom phase of purple common lilac is the date when the first flower is fully open (Caprio et al. 1974).

2End bloom phase of Zabeli honeysuckle is the date when nearly all (at least $95 \%$ ) of all flowers have withered or dried up (Caprio et al. 1974).

${ }^{3}$ First red berry phase of Zabeli honeysuckle is the date when the first berry has turned to a definite red color (Caprio et al. 1974). pecific plant phase. The elevation assigned to a cell was an average of the highest and lowest elevation within a cell. Adjustments made with this second correction factor altered estimates by no more than (+ or -) 3 days.

\section{Grasshopper Data}

Rangeland grasshopper species composition was monitored from 1986-1988 at 9 selected sites throughout Montana. We located sites over a range of long-term plant phenological zones (see, Kemp [1987] Fig. 24.6). All but one of the sites were located within $3.2 \mathrm{~km}$ of a local airport and functioning National Oceanic and Atmospheric Administration (NOAA) weather station. Onsite temperatures were recorded at the Three Forks site because there was no nearby NOAA station. Weather permitting, weekly samples were collected at each of the sites during the intervals shown in Table 2. Species composition and phenological stages for grasshoppers were determined via weekly sweep net collections at each site.

Table 2. Location, elevation, and recording dates for each of 9 sites monitored for rangeland grasshoppers densities, Montana.

\begin{tabular}{lcccc}
\hline \hline & & \multicolumn{3}{c}{ First and last collection dates } \\
\cline { 3 - 5 } Location & Elev. & 1986 & 1987 & 1988 \\
\hline Glasgow & $695 \mathrm{~m}$ & $5 / 27-9 / 24$ & $4 / 16-9 / 22$ & $4 / 19-9 / 14$ \\
Havre & $790 \mathrm{~m}$ & $5 / 21-9 / 24$ & $4 / 16-9 / 21$ & $4 / 18-9 / 15$ \\
Miles City & $799 \mathrm{~m}$ & $5 / 21-9 / 23$ & $4 / 15-9 / 22$ & $4 / 19-9 / 13$ \\
Jordan & $802 \mathrm{~m}$ & $5 / 30-9 / 24$ & $4 / 15-9 / 22$ & $4 / 19-9 / 14$ \\
Fort Benton & $875 \mathrm{~m}$ & $5 / 20-9 / 24$ & $4 / 16-9 / 21$ & $4 / 18-9 / 15$ \\
Broadus & $921 \mathrm{~m}$ & $5 / 21-9 / 23$ & $4 / 15-9 / 23$ & $4 / 20-9 / 13$ \\
Billings & $1,049 \mathrm{~m}$ & $5 / 19-9 / 23$ & $4 / 14-9 / 23$ & $4 / 21-9 / 13$ \\
Great Falls & $1,125 \mathrm{~m}$ & $5 / 28-9 / 24$ & $4 / 17-9 / 21$ & $4 / 18-9 / 15$ \\
Three Forks (DCP) & $1,348 \mathrm{~m}$ & $5 / 2-9 / 12$ & $4 / 7-10 / 1$ & $5 / 3-9 / 23$ \\
\hline
\end{tabular}

Prior to analyses, 6 common rangeland grasshopper species were selected as being representative of the assemblage of species at each site. These were Ageneotettix deorum (Scudder), Amphitornus coloradus (Thomas), Aulocara elliotti (Thomas), Melanoplus infantilis Scudder, $M$. packardii Scudder, and $M$. sanguinipes (F.). Kemp and Onsager (1986) used this assemblage to make standardized comparisons between rangeland grasshopper phenological patterns in 2 different years at Roundup, Mont. While we recognize that the rangeland grasshopper assemblages vary spatially (Kemp et al. 1990a) and temporally, we decided that it was important to restrict comparisons to common species of major economic importance that had similar springtime phenological patterns.

The association between the 3 selected plant development stages and rangeland grasshopper phenology was investigated in several steps. First, as noted above, the Julian date of each plant phenological stage for each grasshopper sample site was estimated based on its elevation, latitude, and longitude (Tables 1 and 2). Second, the methods of Dennis et al. (1986) were used to generate parameters for a model that describes rangeland grasshopper phenology as a function of accumulated heat (Kemp and Onsager 1986, Kemp 1987). Estimates of accumulated heat at each site and year (degree days, $17.8^{\circ} \mathrm{C}$ base) were computed with a sine wave method of Allen (1976) from maximum and minimum temperatures from weather stations. Finally, the methods of Dennis and Kemp (1988) were used to estimate the occurrence of 7 important grasshopper phenological events that are driven by degree days (Fig. 1). Degree day occurrence dates for grasshopper development were then converted to Julian dates so that grasshopper phenological and plant phenological events could be compared. In the case of the estimated date of occurrence of $75 \%$ instar 1 (Fig. 1), we used only those dates which were equal to or greater than the date of the first 


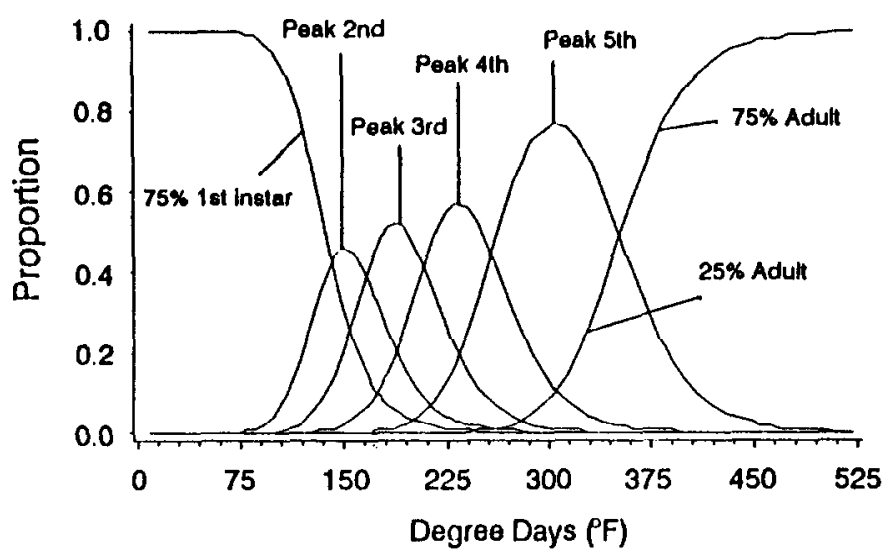

Fig. 1. Example of progression of rangeland grasshopper phenology as estimated by the Dennis-Kemp model (Dennis et al. 1986, Dennis and Kemp 1988).

grasshopper sample date.

Standard ANOVA, stepwise regression, and nonparametric median tests (SAS Institute, Inc. 1988) were used to examine the general relationships between plant phenophases and grasshopper development phases (SAS Institute, Inc. 1988).

\section{Results and Discussion}

\section{Plant and Insect Development}

The average estimated phenophase dates for purple common lilac and Zabeli honeysuckle are contained in Table 3 . Sites were not significant in any of the ANOVAs computed for each phase ( $\alpha$ $=0.05$ ).

Table 4 presents the average yearly progression of plant and insect development at each site and shows a link between rangeland grasshopper and indicator plant phenological stages. Means over sites and years show the $75 \%$ instar 1 stage (spring hatch) for grasshoppers follows the begin bloom phase of purple common lilac by about 10 days. Peak instar 2 was closely linked to the actual date of the end bloom phase of Zabeli honeysuckle, whereas peak instar 3 followed this plant phenological phase by about 10 days. Results also show that peak instar 5 was closely associated with the first red berry phase of Zabeli honeysuckle. An interesting result is that, on average, peak instar 5 and $25 \%$ adult stages occur at approximately the same date. This means that the highest proportions of the fifth instars were found at the time when about $25 \%$ of
Table 3. Average estimated phenophase dates and standard deviations（） of purple common lilac and Zabeli honeysuckle at 9 sites in Montana, 1986-1988.

\begin{tabular}{lccc}
\hline \hline & \multicolumn{3}{c}{ Average' estimated Julian date for } \\
\cline { 2 - 4 } Location & $\begin{array}{c}\text { Begin bloom } \\
\text { purple common } \\
\text { lilac }\end{array}$ & $\begin{array}{c}\text { End bloom } \\
\text { Zabeli } \\
\text { honeysuckle }\end{array}$ & $\begin{array}{c}\text { First red berry } \\
\text { Zabeli } \\
\text { honeysuckle }\end{array}$ \\
\hline Glasgow & $128(7.5)$ & $144(7.6)$ & $172(4.6)$ \\
Havre & $124(6.0)$ & $143(5.1)$ & $170(3.5)$ \\
Miles City & $124(6.4)$ & $147(14.2)$ & $174(10.4)$ \\
Jordan & $127(9.2)$ & $149(18.4)$ & $178(12.0)$ \\
Fort Benton & $126(8.5)$ & $142(9.0)$ & $170(5.1)$ \\
Broadus & $131(10.8)$ & $150(7.5)$ & $177(5.6)$ \\
Billings & $125(9.0)$ & $146(11.1)$ & $173(8.2)$ \\
Great Falls & $134(10.0)$ & $150(11.1)$ & $179(6.8)$ \\
Three Forks (DCP) & $132(9.3)$ & $154(8.7)$ & $181(6.8)$ \\
All sites and years & $128(7.9)$ & $147(9.3)$ & $174(7.0)$ \\
& $($ May 8$)$ & (May 27) & (June 23) \\
\hline
\end{tabular}

'Estimated phenophase dates are based on a 3-year average, 1986-1988.

the population was in the adult stage. Lastly, the $75 \%$ adult stage followed the first red berry of Zabeli honeysuckle by about 14 days.

Over all years and sites, standard deviations ranged between 7 and 11 days. While individual sites showed differing levels of variability, the progression of insect development, on average, was similar to patterns estimated previously (Onsager 1983). Over the 24-26 site-years evaluated, peak instar 2 followed $75 \%$ instar 1 by about 8 days, and peak instars 2 and 3 and peak instars 4 and 5 were separated from one another by an average of 12 and 10 days, respectively. Comparisons made between the timing of grasshopper development stages within plant phase showed significant differences in all cases but one ( $P \leq 0.05, \mathrm{n}=24$ or 26 . Median test, SAS Institute, Inc. 1988). There was no significant difference between the timing of peak instar 5 and $25 \%$ adult stages in terms of the number of days following the first red berry phase of Zabeli honeysuckle $(P \geq 0.05, \mathrm{n}=26$, Median test, SAS Institute, Inc. 1988).

The results of the present study were similar to a smaller study at one site in 1975-1976 (Kemp 1987), where the end bloom phase of Zabeli honeysuckle preceded peak instar 3 rangeland grasshoppers by about 10 days. Table 4 shows that for 26 site-years, the end bloom phase of Zabeli honeysuckle also preceded peak instar 3 by about 10 days.

Table 4. Mean differences and standard deviation ( ) in days between estimated occurrence dates of indicator plants, purple common lilac and Zabeli honeysuckle, and selected estimated occurrence dates of rangeland grasshopper phenological stages ${ }^{1}$.

\begin{tabular}{|c|c|c|c|c|c|c|c|c|c|c|}
\hline \multirow[b]{2}{*}{ Location } & \multirow[b]{2}{*}{ Years } & \multicolumn{3}{|c|}{$\begin{array}{c}\text { Days following the } \\
\text { begin bloom phase of } \\
\text { purple common lilac until }\end{array}$} & \multicolumn{2}{|c|}{$\begin{array}{l}\text { Days following the } \\
\text { end bloom phase of } \\
\text { Zabeli honeysuckle } \\
\text { until }\end{array}$} & \multicolumn{4}{|c|}{$\begin{array}{l}\text { Days following the first red berry phase } \\
\text { of Zabeli honeysuckle until }\end{array}$} \\
\hline & & $\begin{array}{c}75 \% \\
\text { Instar } 1\end{array}$ & Years & $\begin{array}{c}\text { Peak } \\
\text { Instar } 2\end{array}$ & $\begin{array}{c}\text { Peak } \\
\text { Instar } 2\end{array}$ & $\begin{array}{l}\text { Peak } \\
\text { Instar } 3\end{array}$ & $\begin{array}{c}\text { Peak } \\
\text { Instar } 4\end{array}$ & $\begin{array}{c}\text { Peak } \\
\text { Instar } 5\end{array}$ & $\begin{array}{l}25 \% \\
\text { Adult }\end{array}$ & $\begin{array}{l}75 \% \\
\text { Adult }\end{array}$ \\
\hline Glasgow & 3 & $10(4.7)$ & 3 & $21(7.5)$ & $4(5.7)$ & $13(7.5)$ & $-7(3.5)$ & $4(3.8)$ & $4(4.2)$ & $6(6.81)$ \\
\hline Havre & 3 & $1(3.2)$ & 3 & $19(2.5)$ & $0(3.8)$ & $17(2.9)$ & $O(2.0)$ & $9(2.6)$ & $10(1.5)$ & $20(4.2)$ \\
\hline Miles City & 1 & $8(--)$ & 3 & $8(13.6)$ & $-14(9.5)$ & $2(9.5)$ & $-13(5.2)$ & $-3(5.9)$ & $-3(5.7)$ & $8(4.6)$ \\
\hline Iordan & 2 & $14(4.2)$ & 2 & $26(6.4)$ & $3(15.6)$ & $16(16.3)$ & $-6(7.8)$ & $5(9.9)$ & $8(7.8)$ & $21(7.8)$ \\
\hline Ft. Benton & 3 & $10(9.0)$ & 3 & $21(12.7)$ & $5(13.7)$ & $15(10.5)$ & $-4(7.6)$ & $7(6.6)$ & $8(6.1)$ & $19(10.1)$ \\
\hline Broadus & 3 & $7(13.3)$ & 3 & $14(10.8)$ & $-5(3.8)$ & $9(9.5)$ & $-11(6.6)$ & $-2(5.0)$ & $-1(4.0)$ & $10(7.5)$ \\
\hline Billings & 3 & $11(4.6)$ & 3 & $17(0.6)$ & $-3(2.6)$ & $11(5.5)$ & $-8(5.9)$ & $0(4.2)$ & $1(4.6)$ & $9(6.4)$ \\
\hline Great Falls & 3 & $12(13.1)$ & 3 & $23(13.7)$ & $7(15.7)$ & $16(15.1)$ & $-2(12.3)$ & $8(15.0)$ & $8(13.7)$ & $22(14.0)$ \\
\hline Three Forks (DCP) & 3 & $7(2.1)$ & 3 & $11(2.0)$ & $-11(3.5)$ & $-3(6.7)$ & $-19(7.2)$ & $-10(5.5)$ & $-9(5.5)$ & $1(9.5)$ \\
\hline All sites and years & $\overline{24}$ & $10(7.0)$ & $\overline{26}$ & $18(9.4)$ & $-2(10.4)$ & $10(10.5)$ & $-8(8.1)$ & $2(8.5)$ & $3(8.1)$ & $14(9.8)$ \\
\hline
\end{tabular}

'Six selected species used by Kemp and Onsager (1986), Ageneotettix deorum (Scudder), Amphitornus coloradus (Thomas), Aulocara elliotii(Thomas), Melanoplus infantilis Scudder, $M$. packardii Scudder, M. sanguinipes (F.). 
Variation from site to site for the 3 years of the study suggests that additional factors other than heat probably influenced the observed relationship between plant phenology phases and rangeland grasshopper development (see standard deviations, Table 4). For example, the site that was consistently the earliest, grasshoppers relative to plants, was Three Forks. As noted previously, we used a selected assemblage of 6 common economic grasshopper species at each site (Kemp and Onsager 1986, Kemp 1987). While Three Forks had the highest percent of the population in the 6-species assemblage (Table 5), on average more than $73 \%$ of those populations consisted of 1 species, Aulocara elliotti (Thomas). Studies by

Table 5. Percent of rangeland grasshopper populations made up of 6 selected species, for 9 locations and 3 years, Montana.

\begin{tabular}{lccccr}
\hline \hline & \multicolumn{5}{c}{$\begin{array}{c}\text { Percent of population in } \\
\text { 6 species }\end{array}$} \\
\cline { 3 - 5 } Location & 1986 & 1987 & 1988 & $\bar{x}$ & SD \\
\hline Glasgow & 91 & 77 & 85 & 84.3 & 7.0 \\
Havre & 55 & 57 & 74 & 62.0 & 10.4 \\
Miles City & 88 & 76 & 84 & 82.6 & 6.1 \\
Jordan & 72 & 86 & sparse & 79.0 & 9.8 \\
& & & data & & \\
Fort Benton & 95 & 83 & 86 & 88.0 & 6.2 \\
Broadus & 93 & 87 & 91 & 90.3 & 3.1 \\
Billings & 79 & 82 & 84 & 82.7 & 2.5 \\
Great Falls & 89 & 69 & 57 & 71.7 & 16.2 \\
Three Forks (DCP) & 96 & 95 & 96 & 95.3 & 0.6 \\
\hline
\end{tabular}

'Six selected species used by Kemp and Onsager (1986), Ageneotettix deorum (Scudder), Amphitornus coloradus (Thomas), Aulocara elliotti (Thomas), Melanoplus infantilis Scudder, $M$. packardii Scudder, $M$. sanguinipes (F.).

${ }_{2}^{2}$ Densities too low to make accurate estimates.

Kemp and Onsager (1986) show that $A$. elliotti develop more quickly than most of the other members of the 6-species assemblage and suggest that managers of lands that support higher populations of these species will need to assess and treat earlier.

\section{Implications to Pest Management}

Results of this study have implications for the timing of grasshopper management activities in Montana. The advent of purple common lilac bloom should signal to ranchers and pest managers that rangeland grasshopper hatching is underway or will be during the next week or so (also Julian date (JD) $75 \%$ instar $1=30.36+$ $.84 x_{1}$, where $x_{1}=$ the JD of the begin bloom phase of purple common lilac; $P=0.001, r^{2}=0.51$ ). Peak instar 3 , the ideal time to assess rangeland to determine whether there is a problem density (Onsager 1986), occurs on average 10 days after the end bloom phase of Zabeli honeysuckle. In addition to timing of grasshopper development, the results are useful for preparing for appropriate applications of biological or chemical control tactics (Onsager 1986, 1987a, 1987b; Kemp et al. 1988; Berry et al. 1991). Further work on links between vegetation type and grasshopper assemblages (Kemp et al. 1990b) will provide ranchers and land managers with information that will aid in adjusting estimates to local situations.

Frequently, the indicator plants are separated in elevation from the local rangeland grasshopper assemblages. If this difference exceeds $30.5 \mathrm{~m}$, then a lapse rate of about 1 day per $30.5 \mathrm{~m}$ difference in elevation should be used. For example, if a rancher observes the begin bloom phase of purple common lilac near his/her home, that plant phase date would be expected about 2 days later at a nearby site $61 \mathrm{~m}$ higher in elevation (Tables $1,3,4$ ). Additionally, because of heat distribution patterns relative to aspect and slope, managers could expect to see earlier hatching and faster development of grasshoppers on south facing aspects with significant slope.

Additional work will be required to provide for more accurate phenophase estimates based on slope and aspect, as well as elevation (Jackson 1966). Unfortunately, we were not able to make plant observations on site and had to rely on statistically based estimates of phenophase dates. However, our results show that a practical relationship exists between indicator plant and rangeland grasshopper phenology that has utility for scheduling assessment and management activities. The regression relationship noted above between hatching and the begin bloom phase of purple common lilac can be used to establish an initial reference date each year. Tables 3 and 4 can then be used to estimate when different grasshopper development phases will occur. Because range managers do not commonly have access to equipment for computing degree days, we believe the association between grasshopper development and indicator plant phenology will be useful until more complex tools are available. Further, although indicator plant phenology integrates information relative to springtime heat accumulation in a given year, variation in dates between years for a given site can be larger than the overall standard deviations in Table 3. For example, $75 \%$ instar 1 occurred, on average, about 16 days earlier in 1987 compared to 1986. Additionally, the plant phenophase dates also averaged 16 days earlier in 1987 . In a specific example for Billings during 1986, if the mean date of begin bloom for purple common lilac from Table 3 were used (125) instead of the "observed" date (134), grasshopper phenology estimates would be early by 9 days. Therefore, we suggest that actual plant observations be made instead of simply using the mean values for plant phase dates contained in Table 3. Depending on their location, resource managers may find that local situations more closely follow one of the individual sites in Table 4 rather than the overall means.

\section{Literature Cited}

Allen, J.C. 1976. A modified sine wave method for calculating degree days. Environ. Entomol. 5:388-396.

Berry, J.S., W.P. Kemp, and J.A. Onsager. 1991. Integration of simulation models and an expert system for management of rangeland grasshoppers. Al Applications. 5:1-14.

Caprio, J.M. 1966. Pattern of plant development in the western United States. Montana Agr. Exp. Sta. Bull. 607.

Caprio, J.M. 1967. Phenological patterns and their use as climatic indicators, p. 17-43. In: R.H. Shaw (ed), Ground level climatology. American Assoc. Advance. Sci. Pub. 86, Washington, D.C.

Caprio, J.M. 1974. The solar thermal concept in problems related to plant development and potential evapotranspiration, p. 363-364. In: H. Leith (ed), Phenology and seasonality modeling. Springer-Verlag, N.Y.

Caprio, J.M., M.D. Magnuson, and H.N. Metalf. 1970. Instructions for phenological observations. Montana Agr. Exp. Sta. Cir. 250.

Dennis, B., and W.P. Kemp. 1988. Further statistical inference methods for a stochastic model of insect phenology. Environ. Entomol. 17:887-893.

Dennis, B., W.P. Kemp, and R.C. Beckwith. 1986. A stochastic model of insect phenology: Estimation and testing. Environ. Entomol. 15:540-546.

Englund, E., and A. Sparks. 1988. GEOEAS: Geostatistical environmental assessment software user manual. U.S. EPA, EAD, EMSL-LV, P.O. Box 93478, Las Vegas, Nev. 89193-3478.

Hewitt, G.B. 1979. Hatching and development of rangeland grasshoppers in relation to forage growth, temperature, and precipitation. Environ. Entomol. 8:24-29.

Hewitt, G.B. 1980. Plant phenology as a guide in timing grasshopper control efforts on Montana rangeland. J. Range Manage. 33:297-299.

Hopp, R.J. 1974. Plant phenology observation networks, p. 25-43. In: H. Leith (ed), Phenology and seasonality modeling. Springer-Verlag, NY.

Hyder, D.N., and F.A. Sneva. 1955. Effect of form and rate of active ingredient, spraying season, solution volume and type of solvent on mortality of big sagebrush Artemisia tridentata. Oregon Agr. Exp. Sta. Tech. Bull. 35.

Jackson, M.T. 1966. Effects of microclimate on spring flowering phenology. Ecology 47:407-415.

Kemp, W.P. 1987. Predictive phenology modeling in Rangeland pest management, p. 351-368. In. J.L. Capinera (ed), Integrated Pest Management on rangeland: A shortgrass prairie perspective. Westview Press, Boulder, Colo. 
Kemp, W.P., S.J. Harvey, and K.M. ONeill. 1990a. Patterns of vegetation and grasshopper community composition. Oecologia 83:299-308.

Kemp, W.P., S.J. Harvey, and K.M. ONeill. 1990b. Habitat and insect biology revisted: The search for patterns. Amer. Entomologist 36:44-49. Kemp, W.P., and J.A. Onsager. 1986. Rangeland grasshoppers (Orthoptera: Acrididae): Modeling phenology of natural populations of six species. Environ. Entomol. 15:924-930.

Kemp, W.P., J.A. Onsager, and H.E. Lemmon. 1988. Rangeland grasshopper treatment selection: An expert system for decision support in resource management. Al Applications in Natural Resource Management. 2:1-8.

Onsager, J.A. 1983. Relationships between survival rate, density, population trends, and forage destruction by instars of grasshopper (Orthoptera: Acrididae). Environ. Entomol. 12:1099-1 102.
Onsager, J.A. 1986. Factors affecting population dynamics of grasshoppers and control options in the northern Great Plains, p. 15-26. In: Proc. Grasshopper Symp., March 1986, Bismarck, N.Dak.

Onsager, J.A. 1987a. Integrated management of rangeland grasshoppers, p. 196-204, In: J.L. Capinera (ed), Integrated Pest Management on rangeland: A shortgrass prairie perspective. Westview Press, Boulder, Colo.

Onsager, J.A. 1987b. Current tactics for suppression of grasshoppers on Range, p. 60-66, In: J.A. Onsager (ed), Integrated Pest Management on rangeland: State of the art in the sagebrush ecosystem. USDA-ARS. ARS-50.

Robertson, G.P. 1987. Geostatistics in ecology: Interpolating with known variance. Ecology 68:744-748.

SAS Institute Inc. 1988. SAS/STAT user's guide, Release 6.03 Edition. SAS Institute, Inc., Cary, N.C. 